focus on German Studies.

https://journals.uc.edu/index.php/fogs

(ISSN 1076-5697)

Issue 28 (2021)

Book Review

Transnational Nazism: Ideology and Culture in German-Japanese

Relations, 1919-1936 by Ricky W. Law, Cambridge University Press, 2020.

360pp. \$29.99.

Daniel Moody

University of Cincinnati

How to Cite: Moody, Daniel. "Transnational Nazism: Ideology and Culture in German-Japanese Relations, 1919-1936 by Ricky W. Law". focus on German Studies 28, no. 28, 2021, pp. 247-252. DOI: 10.34314/FOGS2021.00020. 
focus on German Studies.

\section{Transnational Nazism: Ideology and Culture in German-Japanese}

\section{Relations, 1919-1936 by Ricky W. Law, Cambridge University Press, 2020.}

\section{0pp. \$29.99.}

\section{Daniel Moody}

As evidenced by the rise in extreme far-right movements in the last few years, the ideology of the National Socialist movement did not gain traction only within Nazi Germany, but rather around the world. In the time leading up to World War II, a growing relationship between Nazi Germany and militarist Japan encouraged the spread of Nazi ideology to Japan and led to the development of the Tokyo-Berlin Axis.

Ricky W. Law's 2019 book Transnational Nazism: Ideology and Culture in German-Japanese Relations, 19191936 (Cambridge University Press) examines the mass media of these two countries during the interwar period and how the national media of these two distant countries mutually shaped and influenced perceptions of one another. Law examines a variety of media sources from both countries. From the Japanese perspective, he focuses on newspapers, lectures and pamphlets, nonfiction, and German language textbooks. From the German perspective, he examines the role of Japan and the Japanese people in Nazified newspapers, films, nonfiction, and voluntary associations. Law's close investigation of these media sources sheds light on an often-overlooked aspect of international relations during this time period.

Law's book is divided into two parts, one focusing on each of the two countries. Part I focuses in on Transnational Nazism in Japan and is further broken up into four chapters dealing with Germany in various different media: newspapers, lectures and pamphlets, nonfiction, and language textbooks. Part II focuses on Transnational Nazism in Germany and is also broken up into four chapters dealing with the perceptions of 
focus on German Studies.

Japan in newspapers, films, nonfiction, and in voluntary associations.

Law opens his book with an anecdote about an incident in 1934 when a Japanese businessman applied to trademark the name "Hitler" as a brand name for bicycles and tricycles (1). This application was swiftly countered by the German Embassy asking the Japanese Foreign Ministry to intervene for taking the Führer's name in vain. Law describes this incident as emblematic of the political and cultural relationships of Germany and Japan before the resolution of the Anti-Comintern Pact of 1936. Law goes on to argue that this international incident demonstrates two key arguments for his book. First, it is demonstrative of the mutual excitement for Hitler shared by Germans and Japanese. Law argues that the fact that the name was well enough known and admired to be used for a valuable brand of consumer goods is evidence of what he calls “Transnational Nazism” (1). This incident supports the second major argument of his book: "words and activities in civil society helped to shape German-Japanese mutual perceptions” (2).

The first chapter of Part I deals with the presence of Germans and Germany in Japanese newspapers. Law makes the argument that the Japanese press took an extreme interest in German attributes; "Germanness" and its myriad manifestations became a recurring topic within the Japanese press (32). He goes on to note that the Japanese press frequently interpreted events such as the post 1918 chaos or the Nazi revolution of 1933 as reflective of the innate qualities of Germans. By January of 1935, much of the Japanese press adopted Transnational Nazism and transitioned from an affinity for rightist Germany, to enthusiasm for Hitler and his regime. Law asserts that the style of Japanese journalism, driven by personalities, was perfectly suited for someone such as Hitler and the Hitler myth that could be easily sold to the newspaper buying public (65).

The second chapter of Law's book focuses on Germany in lectures and pamphlets in Japan. Law contrasts the issues in both countries whereas Nazis and communists were engaged in street battles in 
focus on German Studies.

https://journals.uc.edu/index.php/fogs

(ISSN 1076-5697)

\section{focus} on German Studies

Germany, the sympathizers to the ideology in Japan clashed through words in orations and booklets.

Although the events in far-off Germany had no immediate effects on Japan, they still, as Law argues, “elicited strong emotions as if the stakes involved not just Germany’s soul, but Japan’s as well” (78). Law posits that the adaptation of the Anti-Comintern Pact was something of a validation of these sentiments. He argues that the formalization of relations with Germany reduced the very latitude used by lecturers and pamphleteers to demonstrate their support for Hitler and Nazism.

The third chapter of Part I focuses in on Germany within Japanese nonfiction, primarily within books on current affairs, politics, economy, and contemporary history. The genre of these works is varied and includes monographs, biographies, travelogues, memoirs, and encyclopedic anthologies. Law argues that the medium of these works allowed for authors to explore themes that newspaper articles and pamphlets could not. He goes on to argue that discussions about Germany within these types of texts were often not just about Germany, but also about Japan. Problems caused by the world economic crisis such as unemployment, social tension, political impasse, and limits on international trade were present in both Germany and Japan. Law contends that Japanese nonfiction dealing with Germany during this time exists in two phases. The first phase consists of broad inquiries into political economy and literature, and the second phase is marked by reactions to Hitler and Nazism.

The fourth chapter of Part I deals with German in language textbooks. Law asserts that language instructors serve as extremely powerful cultural mediators and influence and shape perceptions of the image of the country and culture where the language is spoken. As such, language learning makes it possible to engage in the most intense forms of intercultural experience. Law argues that when the rightist movement took root in Germany many linguists chose to accommodate the regime and align themselves with Nazism and Hitler; many language teachers embodied the values of Transnational Nazism in their voluntary praise 
focus on German Studies.

for Nazi ideology and Hitler.

Part II transitions into the discussion of Japan within the German context. Chapter Five deals with the perception of Japan through German newspapers. Law describes the presence of Japan within the German press as morphing through three different phases. The first phase is from 1918 until the conquest of Manchuria in 1931. During this time, Law asserts that Japan only caught the attention of newsmen whose papers had the financial wherewithal and interests beyond partisanship. Eventually, almost overnight, Japan morphed into a topic of controversy for Germans with the increased interest in the Sino-Japanese struggle. After the Nazi regime decimated the press, Law argues that because of a mutual respect for Japan as a great power, Transnational Nazism accepted and accommodated Japan into its worldview.

Chapter six of Part Two concerns itself with the perception of Japan through film in Germany. Law proposes that film, as a medium, offered an alluring alternative to what readers could glean from words and photographs in a newspaper article. He describes the presentation of Japan in German cinema as resembling a sentimental romance film.

Chapter seven focuses in on Japan in German nonfiction works. Like the corresponding chapter from Part I, this section deals heavily with travelogues. Law makes the argument that the atmosphere following the adoption of the Anti-Comintern Pact allowed for easier production of works with a politicized message or agenda.

The final chapter of the book deals with perceptions of Japan with respect to voluntary associations in Germany. Law argues that the relations fostered by the Anti-Comintern Pact and Transnational Nazism allowed for the Deutsch-Japanische Gesellschaft to attain more power than any other binational organization in Germany.

Law's book is an interesting and insightful overview of German-Japanese relations in the interwar 
focus on German Studies.

https://journals.uc.edu/index.php/fogs

period. He provides an excellent framework of reference and historical context for the development of relations with respect to national media. His analysis is well structured into multiple chapters of focus and further breaks those chapters down into subchapters. Part I, which deals with perceptions of Germany within Japanese media is very well researched and organized. Part II is also well researched and organized, but it appears as though the analysis of the perceptions of Japan within Germany does not go as deep as Part I. 